\title{
層間はく離を有する積層板の超音速パネルフラッタ解析*1 Supersonic Panel Flutter Analysis of Delaminated Plates
}

\author{
亀 山 正 樹*2 ·花 輪 達 也*2 ·胡寧*2 $\cdot$ 福 永 久 雄 $* 2$ \\ Masaki Kameyama, Tatsuya Hanawa, Ning Hu and Hisao Fukunaga
}

Key Words : Aeroelasticity, Composite Materials, Supersonic Panel Flutter, Delamination

\begin{abstract}
The present paper treats a supersonic panel flutter of simply-supported symmetrical laminates with a delamination. The panel flutter characteristics of composite laminates are obtained by a finite element method based on the Mindlin plate theory and a quasi-steady aerodynamics based on the linearized piston theory in this paper. The penalty function method is adopted to ensure the displacement continuity condition at the delamination front, and the linear spring model is also adopted to describe the effect between the delaminated surfaces. The panel flutter boundary is obtained by solving the eigenvalue equation as the flutter equation. The validity of the present method and the effects of the size and location of a delamination on the panel flutter characteristics of laminated plates are examined through the numerical results.
\end{abstract}

\section{1. 緒 言}

炭素繊維強化複合材料に代表される先進複合材料は，金 属材料に比べて比強度・比剛性に優れた特性を有し，また 設計に関する自由度が高いことから, 近年, 厳しい軽量化 が要求される航空宇宙分野において主要構造部材への適用 が拡大しつつある。しかし, 積層複合材構造は, 異物衝突 による面外衝撃荷重を受けることによって層間はく離や繊 維破断，母材き裂等の内部損傷を生じやすく，一度これら の損傷が発生すると剛性や強度が著しく低下する1). 特に, 運用中の航空機においては空気力ゃ弾性力, 慣性力が繰り 返し作用するため，結果としてより重大な損傷や事故を誘 発する危険性が指摘されている。よって，構造物の健全性 を保証し安全に運用するためには, 内部損傷を有する構造 物が外力を受けた際の特性解析・挙動解析が重要となる. 本 論文では, 航空機構造設計において重要な設計基準のひと つである空力弾性特性と複合材構造における内部損傷の関 係について検討を行うこととする。

空力弾性不安定現象のひとつであるパネルフラッタは, 超 音速空気流に曝された航空宇宙機の外板 (パネル) の自励 振動現象であり ${ }^{2)}$, 翼の曲げ・ねじりフラッタとは異なり短 時間で直ちに破壊することは少ないものの, 繰り返し応力 によって疲労破壊を引き起こすことの多い危険な振動現象 である。 そのため, パネルフラッ夕特性は高速飛翔体構造 の設計上重要な基準のひとつとなっており，これまでに多 くの研究がなされてきだ 5).

損傷を有さない健全な複合材積層構造を対象とした場合, 繊維配向角 - 境界条件 - 空気流入角度 - 面内荷重 - 熱荷重

\footnotetext{
*1 C) 2008 日本航空宇宙学会

平成 19 年 4 月 25 日原稿受理

*2 東北大学大学院工学研究科航空宇宙工学専攻
}

等の種々の条件がパネルフラッタ特性におよぼす影響に関 する検討6) を始めとして，パネルフラッタ動圧最大化を目 的とした積層構成最適化7)，スマート材料を用いた能動パ ネルフラッタ抑制8) に関しても活発に検討されている。

一方, 損傷を有する複合材積層構造を対象とした場合, 内 部損傷として母材き裂，あるいは，層間はく離を取り扱う 研究例が多い.母材き裂を取り扱った研究として, 例えば Pidaparti らは，層内き裂9)，あるいは，貫通き裂10)を有 する積層板を対象として，き裂が固有振動数，および，パ ネルフラッタ限界におよぼす影響について検討を行う一方 で, Strganac ら 11) は層内き裂を有する片持対称積層板の 空力荷重下における損傷進展解析を行っている。また，層 間はく離を取り扱った研究として，例えばShiau ${ }^{12)}$ は，層 間はく離を有する 2 次元積層パネルを対象として, 積層構 成，層間はく離の位置・大きさがパネルフラッタ限界にお よぼす影響について検討を行っている。他に, 板中央面に 層間はく離を有する片持対称積層板を対象として, はく離 が曲げ・ねじりフラッタ速度におよぼす影響，および，積 層板表面に貼付した圧電アクチュエータによる能動突風応 答制御の有効性を検討した例13) もある.

ここで，層間はく離を有する積層板のフラッ夕解析に着 目すると, 従来の研究 ${ }^{12,13)}$ では, はく離部の上下面が同じ たわみ形状を示すように拘束条件を与えた上で固有值解析 に基づいた安定性解析を行うことにより，フラッ夕特性を 簡便に得ることを可能にしている.ところが, Shen ら ${ }^{14)} に$ よる片持積層はりの振動実験を通して明らかなように, 例 えば層間はく離がある程度の大きさを有した場合, あるい は, 板中央面から離れた位置にある場合, 解析においては く離部の上下面の開口を併せて考慮する必要が生じる。こ のことは, はく離部の上下面の接触問題をより厳密に取り

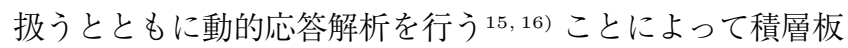


のフラッタ特性を得る必要があることを示し, 計算コスト の著しい増加をもたらすこととなる。よって, 前述したよ うな固有值解析に基ついた安定性解析の適用可能範囲に関 して予め詳細に検討する必要があるが，これまでのところ， そのような報告はなされていない.

そこで，本論文では，周辺単純支持された層間はく離を 有する対称積層板を対象として超音速パネルフラッタ解析 を行い, はく離の大きさ・位置が積層板のパネルフラッタ 特性におよぼす影響に関して検討を行う。パネルフラッタ 特性を得るために, 構造解析には 1 次せん断変形理論に基 づく有限要素法, 空力解析には線形ピストン理論に基づく 準定常空気力 ${ }^{17)}$ を用いて安定性解析を行う. 数值計算例を 通じて, 本解析方法の妥当性および適用可能範囲に関して 検討を行う.

\section{2. 基 礎 式}

2.1 パネルフラッタ特性 第 1 図に示すように, 周辺 単純支持された板厚, および, 密度の一様な対称積層板の 上面が一様流速度 $V$ の $x$ 軸に平行な超音速空気流に曝され ている場合のパネルフラッタ特性に関する基礎式は, 積層 板上面に作用する空気力の算出に準定常空気力17) を適用す るとき, 有限要素法に基づいて次式で与えられる。

$$
\begin{aligned}
& {\left[M_{\mathrm{S}}\right]\{\ddot{x}\}+\left[K_{\mathrm{S}}\right]\{x\}} \\
& \quad=-\left(\lambda\left[K_{\mathrm{A}}\right]\{x\}+\mu\left[C_{\mathrm{A}}\right]\{\dot{x}\}\right) \\
& \quad=-\left(\lambda\left[K_{\mathrm{A}}\right]\{x\}+\frac{\mu}{\rho_{\mathrm{m}} h}\left[M_{\mathrm{S}}\right]\{\dot{x}\}\right)
\end{aligned}
$$

ここで, $M_{\mathrm{S}}$ は質量マトリックス, $K_{\mathrm{S}}$ は剛性マトリックス, $K_{\mathrm{A}}$ は空力マトリックス, $C_{\mathrm{A}}$ は空力減衰マトリックス, $x$ は節点変位ベクトルである。 $\lambda$ は動圧パラメータ, $\mu$ は空 力減衰パラメータを表し, 一様流動圧 $q$ およびマッ八数 $M$ $(\sqrt{2}<M<5)$ を用いて次式で与えられる.

$$
\lambda=\frac{2 q}{\sqrt{M^{2}-1}}, \quad \mu=\lambda \frac{1}{V} \frac{M^{2}-2}{M^{2}-1}
$$

また, $\rho_{\mathrm{m}}$ は板の密度, $h$ は板厚である.なお, $\lambda=0$ の場 合は自由振動の解を与える。

(1) 式において, モード座標系 $a$ を導入し, 調和振動を 仮定することにより次式が得られる.

$$
\left(\left[\Omega^{2}\right]+\lambda[\Phi]^{\mathrm{T}}\left[K_{\mathrm{A}}\right][\Phi]\right)\left\{a_{0}\right\}=\kappa[I]\left\{a_{0}\right\}
$$

ここで， $\Omega$ は固有角振動数を対角成分にもつマトリックス, $\Phi$ は固有振動モードマトリックス， $I$ は単位マトリックス, $a_{0}$ は $a$ の振幅を表す. (3) 式で与えられる複素固有值問題 より，設定動圧に対する複素固有值 $\kappa$ が求まる.

$$
\begin{aligned}
\kappa & =\kappa_{\mathrm{R}}+i \kappa_{\mathrm{I}} \\
& =-\left(\omega^{2}+\frac{\mu}{\rho_{\mathrm{m}} h} \omega\right) \\
& =\left(\omega_{\mathrm{I}}^{2}-\omega_{\mathrm{R}}^{2}-g_{\mathrm{a}} \omega_{\mathrm{R}}\right)+i\left(-g_{\mathrm{a}} \omega_{\mathrm{I}}-2 \omega_{\mathrm{R}} \omega_{\mathrm{I}}\right)
\end{aligned}
$$

ここで，

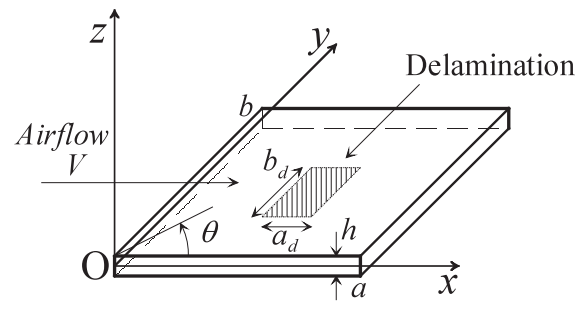

第 1 図 対称積層板

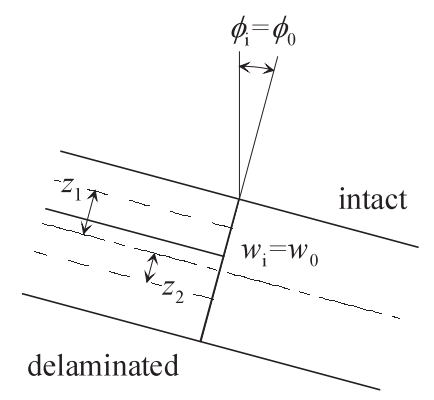

第 2 図 はく離前縁部における変位の連続条件 ${ }^{19)}$

$$
\omega=\omega_{\mathrm{R}}+i \omega_{\mathrm{I}}
$$

である。

ある設定動圧 $\lambda$ において (3) 式の固有值問題を解き, 得 られた複素固有值 $\kappa$ を用いることにより安定性の判別を行 う. 安定判別式は次式で与えられる18).

$$
\frac{\kappa_{\mathrm{I}}^{2}}{\kappa_{\mathrm{R}}}>g_{\mathrm{a}}^{2}=\left(\frac{\mu}{\rho_{\mathrm{m}} h}\right)^{2}
$$

特に, 空力減衰の影響を無視する場合 $(\mu=0)$ には, $g_{\mathrm{a}}=0$ となることから, 固有值 $\kappa$ が実固有值から複素固有值に変 化するときの $\lambda$ が限界フラッタ動圧パラメータ $\lambda_{\mathrm{cr}}$ となる. 本研究における数值計算例では, 簡単のため空力減衰効果 を無視する。なお，限界フラッ夕動圧パラメータ $\lambda_{\mathrm{cr}}$ の決 定に際しては， $\lambda$ を徐々に増加させて繰り返し (3) 式の固 有值解析を行う.

2.2 はく離領域のモデル化 初めに，層間はく離を有 する積層板の構造解析を行う場合，はく離前縁部において 変位の連続条件を満足する必要がある。本研究では, ミン ドリン板理論に基づく有限要素解析において, せん断変形 の影響を考慮した 9 節点 45 自由度のアイソパラメトリッ ク平面要素を用いる．第 2 図に示すように，はく離前縁部 において変位の連続条件は次式で与えられる19).

$$
\begin{aligned}
& w_{i}=w_{0}, \quad \phi_{x i}=\phi_{x 0}, \quad \phi_{y i}=\phi_{y 0}, \\
& u_{i}=u_{0}+z_{i} \phi_{x 0}, \quad v_{i}=v_{0}+z_{i} \phi_{y 0}
\end{aligned}
$$

ここで, 添字 $i(=1,2)$ は, はく離領域の上層部分·下層 部分を示し，0ははく離の生じていない領域を示す。なお, 本研究では，(6) 式を考慮するためにペナルティ関数法を 適用した。

また，はく離面において接触問題を考慮する必要がある. 本研究では，はく離上下面の対応する 2 節点間を $z$ 軸方向 


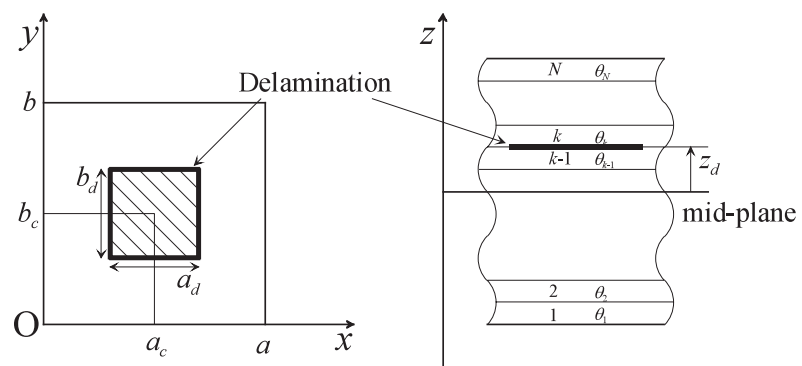

第 3 図 積層板における層間はく離の位置と大きさ

の仮想バネで接続することを考える20)．節点間を接続する 仮想バネが非常に剛な場合（以降，拘束モデル21) とする), はく離部の上層と下層は開口せず，等しく振動する。なお， 本研究では, 仮想バネの剛性値は経験的に $10^{8}$ とする。一 方，節点間を仮想バネで接続しない場合（以降，自由モデ ル22) とする)，はく離部の上層と下層の開口，㧍よび，食 い込みを許容することとなる。

以降, 層間はく離中心点の位置 $\left(a_{\mathrm{c}}, b_{\mathrm{c}}, z_{\mathrm{d}}\right)$, および, 層 間はく離の大きさ $\left(a_{\mathrm{d}}, b_{\mathrm{d}}\right)$ を，第 3 図に示すように定義 し, 各々の值は基準長さにより無次元化して表示する.

2.3 はく離を有する積層板のパネルフラッタ解析 本研 究に扔いて, 層間はく離を有する積層板の超音速パネルフ ラッ夕解析は， 2.1 節および 2.2 節に基づいて行われるが, 本数值解析に拀けるその他の留意点に関して以下に示す.

(1) 空力・空力減衰マトリックス $K_{\mathrm{A}}, C_{\mathrm{A}}$ の算出 ${ }^{12)}:(1)$ 式に関して，層間はく離を有する積層板に作用する準定常 空気力の算出にあたり, はく離領域においては超音速空気 流に曝される上層部分の変位を用いて空気力を決定し，同 じく上層部分に空気力を作用させる.

(2) 固有振動モードに関する仮定: 層間はく離を有する 積層板を対象として自由振動解析 $(\lambda=0)$ を行って得ら れる固有振動モードは, 質量マトリックス $M_{\mathrm{S}}$ に関して正 規直交化される。よって, 限界フラッタ動圧パラメータ $\lambda_{\mathrm{cr}}$ は，2.1節に示すように $\lambda$ を徐々に増加させて繰り返し (3) 式の固有值解析を行うことにより決定できる.

(3) はく離面の開口・接触の取り扱い: 層間はく離を有 する積層板の振動において, 層間はく離の位置と大きさに よっては，はく離面が開口と接触を繰り返すことが知られ ている16). 本研究において, パネルフラッ夕特性は開口 (本 研究では食い込みも許容) と接触（本研究では開口しない 状態に対応）を自由モデル・拘束モデルとして個別に取り 扱い，(3) 式の固有值解析に基づいた安定性解析を行うこ とにより得られ，両者を同時には考慮していない。

\section{3. 数值計算例および考察}

3.1 基本検証 初めに, 周辺単純支持されたアスペクト 比 $a / b=1$ の等方性板について超音速パネルフラッタ解析 を行うことにより，その妥当性に関する検討を行う。ここ で，対象とする等方性板のポアソン比 $\nu$ は 0.3 とした。 な お，構造解析において，解析対象となる等方性板を主流方
第 1 表 Sander ら ${ }^{18)}$ との固有角振動数・フラッタ限界の比較

\begin{tabular}{llllll}
\hline & \multicolumn{2}{c}{ Natural frequencies } & & \multicolumn{2}{c}{ Flutter bound } \\
\cline { 2 - 3 } \cline { 5 - 6 } & \multicolumn{1}{c}{ First } & Second & & $\lambda_{\text {cr }}^{*}$ & $\kappa_{\mathrm{cr}}^{*}$ \\
\hline Present & 389.56 & 2434.13 & & 512.33 & 1846.62 \\
Ref. 18) Exact & 389.636 & 2435.23 & & 512.651 & 1848.21 \\
Ref. 18) Comp. & 389.7 & 2438 & 512.2 & 1844 \\
\hline
\end{tabular}

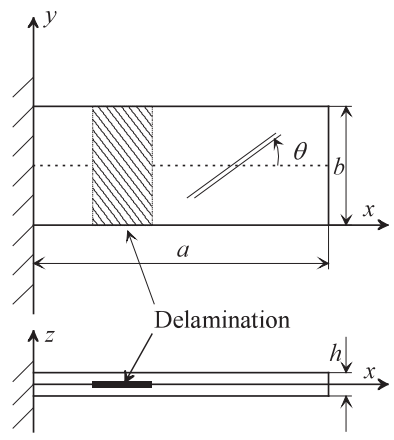

第 4 図 はく離を有する片持対称積層はり $\left(a=2 a_{\mathrm{c}}=127 \mathrm{~mm}\right.$, $\left.b=b_{\mathrm{d}}=12.7 \mathrm{~mm}, h=1.02 \mathrm{~mm}\right)$

向に 30 分割，板幅方向に 30 分割したモデルを用いる. (3) 式において採用モード次数は 1 50 次とし，(5) 式により 安定性判別の対象となるモード次数は $1 \sim 20$ 次とした.

第 1 表は, Sander ら ${ }^{18)}$ の有限要素解析で得られた固有 角振動数, および, フラッ夕限界とそれらの厳密解との比 較を示す。なお, 動圧パラメー夕, 㧍よび, 角振動数は次 式に示すように無次元化している.

$$
\lambda^{*}=\frac{a^{3}}{D} \lambda, \quad \kappa_{\mathrm{R}}^{*}=\frac{\rho_{\mathrm{m}} h a^{4}}{D} \kappa_{\mathrm{R}}=\frac{\rho_{\mathrm{m}} h a^{4}}{D} \omega_{\mathrm{I}}^{2}
$$

ここで, $D$ は板の曲げ剛性を示す。これより, 本研究で得 られた固有角振動数, および, フラッ夕限界は既存の結果 と非常に良い一致を示している。

次に，第 4 図に示すような層間はく離を有する $[0 / 90]_{2 \mathrm{~s}}$ 片持 CFRP 積層はりについて振動解析を行うことにより, その妥当性に関する検討を行う。第 2 表は, CFRP一方向 材の材料定数を示す. なお人, 構造解析において, 解析対象 となる積層はりを長手方向に 50 分割したモデルを用いる.

第 3 表は, $\mathrm{Hu}$ ら 20) の有限要素解析で得られた 1 次固有 振動数との比較を示す.これより, 本研究で得られた 1 次 固有振動数は既存の結果と非常に良い一致を示している.

以降，積層はり，および，積層板を対象としたパネルフ ラッタ特性の検討において, 動圧パラメータ, および, 複 素固有值の実部・虚部は次式に示すように無次元化する.

$$
\begin{aligned}
& \lambda^{*}=\frac{a^{3}}{D} \lambda, \\
& \left(\omega^{*}\right)^{2}=\kappa_{\mathrm{R}}^{*}=\frac{\rho_{\mathrm{m}} h a^{4}}{\pi^{4} D} \kappa_{\mathrm{R}}, \quad\left(\alpha^{*}\right)^{2}=\kappa_{\mathrm{I}}^{*}=\frac{\rho_{\mathrm{m}} h a^{4}}{\pi^{4} D} \kappa_{\mathrm{I}} \\
& D=\frac{E_{1} h^{3}}{12\left(1-\nu_{12} \nu_{21}\right)}
\end{aligned}
$$

3.2 層間はく離を有する積層はりの超音速パネルフラッ タ特性 数值計算例として第 5 困に示す $[0 / 90]_{\mathrm{S}}$ 両端単純 
第 2 表 CFRP 一方向材の材料定数

\begin{tabular}{|c|c|c|c|c|c|}
\hline $\begin{array}{c}E_{1} \\
{[\mathrm{GPa}]}\end{array}$ & $\begin{array}{c}E_{2} \\
{[\mathrm{GPa}]}\end{array}$ & $\begin{array}{c}G_{12}=G_{13} \\
{[\mathrm{GPa}]}\end{array}$ & $\begin{array}{c}G_{23} \\
{[\mathrm{GPa}]}\end{array}$ & $\nu_{12}$ & $\begin{array}{c}\rho_{\mathrm{m}} \\
{\left[\mathrm{kg} / \mathrm{m}^{3}\right]}\end{array}$ \\
\hline 134 & 10.3 & 5.00 & 3.28 & 0.33 & 1480 \\
\hline \multicolumn{6}{|c|}{ 第 3 表 $\mathrm{Hu} ら^{20)}$ との 1 次固有振動数の比較 } \\
\hline \multirow{2}{*}{$\begin{array}{c}a_{\mathrm{d}} \\
{[\mathrm{mm}]}\end{array}$} & \multirow{2}{*}{$\begin{array}{c}z_{\mathrm{d}} \\
{[\mathrm{mm}]}\end{array}$} & \multicolumn{2}{|c|}{ Present $[\mathrm{Hz}]$} & \multicolumn{2}{|c|}{ Ref. 20) $[\mathrm{Hz}]$} \\
\hline & & Free* & Cons. ${ }^{* *}$ & Free* & Cons. ${ }^{* *}$ \\
\hline 0 & 0 & \multicolumn{2}{|c|}{82.21} & \multicolumn{2}{|c|}{81.87} \\
\hline \multirow[t]{2}{*}{50.8} & 0 & 76.821 & 76.821 & 76.522 & 76.522 \\
\hline & 0.3825 & 80.924 & 80.942 & 80.620 & 80.637 \\
\hline \multirow[t]{2}{*}{101.6} & 0 & 56.960 & 56.960 & 56.556 & 56.556 \\
\hline & 0.3825 & 73.295 & 74.030 & 72.717 & 73.778 \\
\hline
\end{tabular}

*自由モデルによる解析結果, **拘束モデルによる解析結果.

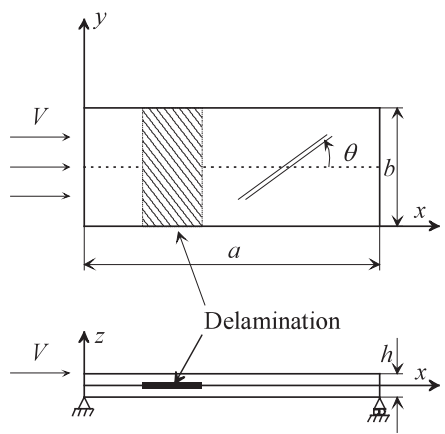

第 5 図 はく離を有する両端単純支持対称積層はり $(a / b=200)$

第 4 表 CFRP 一方向材の材料定数

\begin{tabular}{ccc}
\hline$E_{1} / E_{2}$ & $G_{12} / E_{2}$ & $\nu_{12}$ \\
\hline 13.643 & 0.493 & 0.32 \\
\hline
\end{tabular}

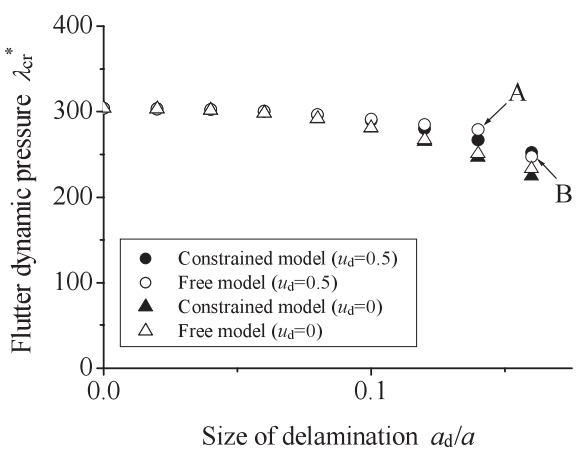

第 6 図 はく離の大きさがフラッタ動圧におよぼす影響 $\left(a_{\mathrm{c}} / a=0.5\right)$

支持 CFRP 積層はりを考え，その一方向材の材料定数とし て文献 12) と同じ第 4 表の值を用いた。なお，はく離領域 のモデル化において拘束モデルを適用した場合, 要素分割 数と採用モード次数, 仮想バネの剛性値等の適切な設定を 行えば, 得られるパネルフラッタ限界は, 幅方向に一様な 2 次元問題を扱った文献 12) の解析結果と非常に良く一致 する．本解析において，解析対象となる積層はりを主流方 向に 100 分割したモデルを用いる。また，(3) 式において 採用モード次数は 1〜 50 次とし，(5) 式により安定性判別 の対象となるモード次数は 1 20 次とした。

第 6 図に，両端単純支持積層はりの層間はく離の大きさ

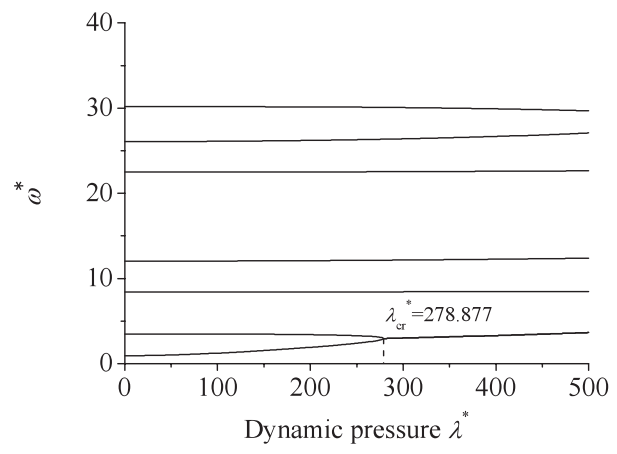

(a) $\omega^{*}$ の履歴

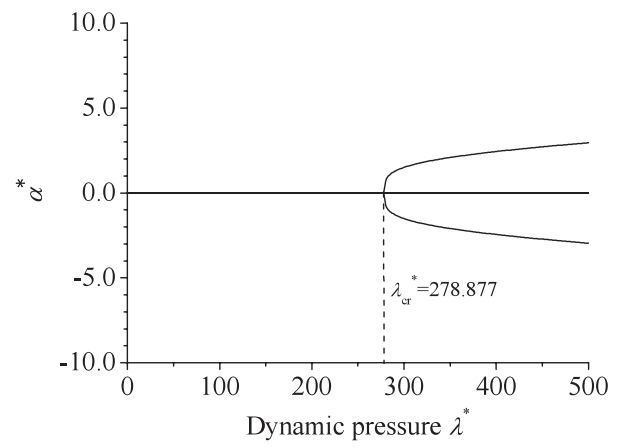

(b) $\alpha^{*}$ の履歴

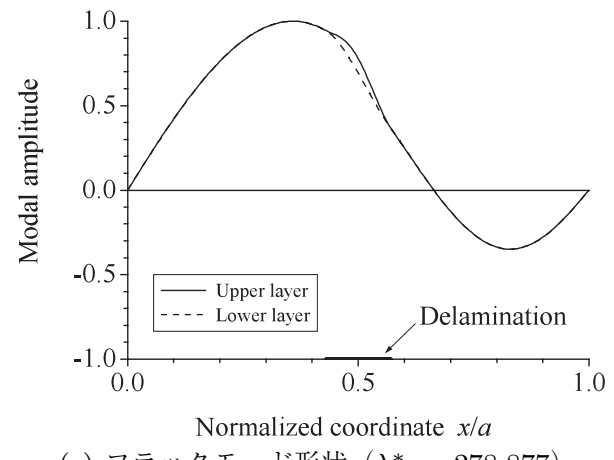

(c) フラッタモード形状 $\left(\lambda_{\mathrm{cr}}^{*}=278.877\right)$

第 7 図 $\mathrm{A}$ 点 $\left(a_{\mathrm{d}} / a=0.14\right)$ のパネルフラッタ特性 $\left(u_{\mathrm{d}}=0.5\right.$, 自由モデル）

がフラッタ動圧パラメータの值におよぼす影響を示す。こ こで, $u_{\mathrm{d}}\left(=z_{\mathrm{d}} /(h / 2)\right)$ は板厚方向の無次元化した座標であ る。この図より，はく離の板厚方向の位置によらず，拘束モ デル，および，自由モデルともにはく離が大きくなるにつれ てフラッタ動圧パラメータの值が小さくなることがわかる. また，はく離の大きさが構造寸法と比較して十分小さい場 合 $\left(a_{\mathrm{d}} / a<0.1\right)$ には, 拘束モデル，㧍よび，自由モデル の場合で得られるフラッタ動圧パラメータの值に差が生じ ないが，やや大きくなるとモデル間で差が生じることがわ かる. 第 7 図, 第 8 図は, 第 6 図上の $\mathrm{A}$ 点 $\left(a_{\mathrm{d}} / a=0.14\right)$, および, $\mathrm{B}$ 点 $\left(a_{\mathrm{d}} / a=0.16\right)$ において, 自由モデルを適 用した場合に得られる $\omega^{*}, \alpha^{*}$ の履歴，および，フラッ夕 モード形状の比較を示す.ここで, 第 7 図 (c), 第 8 図 (c) 中の横軸上の太線ははく離を表している。第 7 図より, A 点では $x$ 軸方向に半波数 1 のモードと半波数 2 のモードの 固有振動数 $\omega_{\mathrm{I}}$ が $\lambda^{*}$ の増加に伴って徐々に近づき， $\omega^{*}$ が共 


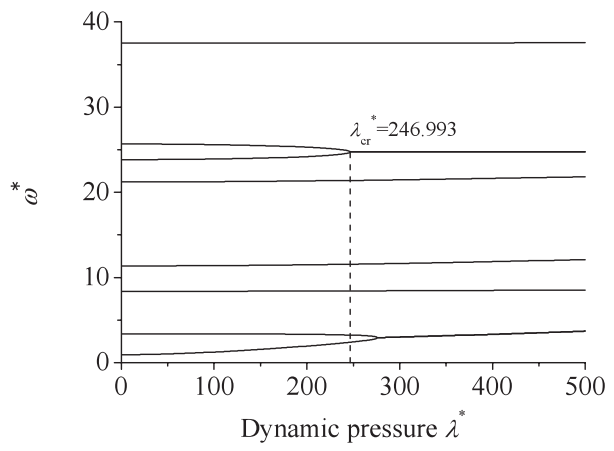

(a) $\omega^{*}$ の履歴

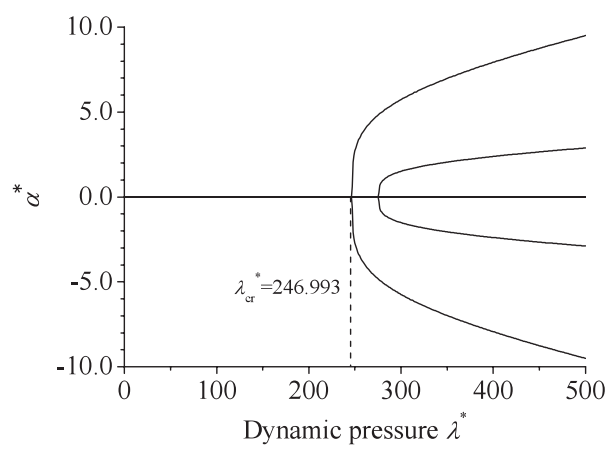

(b) $\alpha^{*}$ の履歴

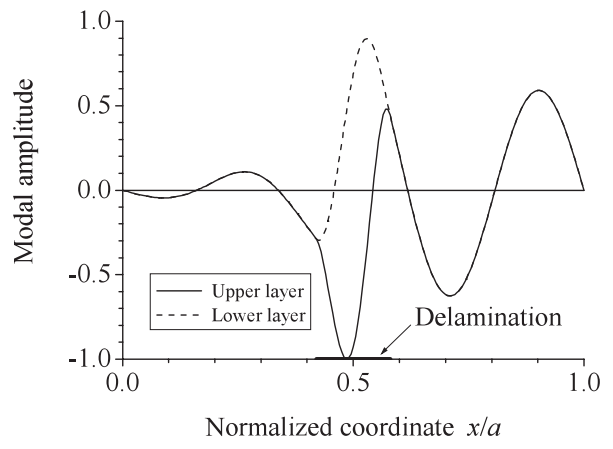

(c) フラッタモード形状 $\left(\lambda_{\mathrm{cr}}^{*}=246.993\right)$

第 8 図 $\mathrm{B}$ 点 $\left(a_{\mathrm{d}} / a=0.16\right)$ のパネルフラッタ特性 $\left(u_{\mathrm{d}}=0.5\right.$, 自由モデル

役解をもつと同時に $\alpha^{*}$ が正值となり， $\lambda_{\mathrm{cr}}^{*}=278.877$ にお いてパネルフラッタが生じていることがわかる。一方，第 8 図より，B点ではより高次の振動モードの固有振動数 $\omega_{\mathrm{I}}$ が $\lambda^{*}$ の増加に伴って徐々に近づき， $\omega^{*}$ が共役解をもつと 同時に $\alpha^{*}$ が正值となり， $\lambda_{\mathrm{cr}}^{*}=246.993$ においてパネルフ ラッタが生じていることがわかる。つまり，はく離が小さ い場合には，モデルによらず，第 7 図 (c) に示すように， $x$ 軸方向に半波数 1 のモードと半波数 2 のモードの固有振動 モードの連成によって半波数 2 のフラッタモード形状を呈 するパネルフラッタが生じる一方，はく離が大きい場合に は，第 8 図 (c) に示すように, 自由モデルを用いた場合に より高次の固有振動モードの連成による，はく離面が大き く開口するようなパネルフラッタが生じる。また，モデル 間のフラッタ動圧パラメータの值の相違は, パネルフラッ 夕が生じる際に連成する固有振動モードのモード次数に起 因する。なお，自由モデルの場合は，低次の固有振動モー

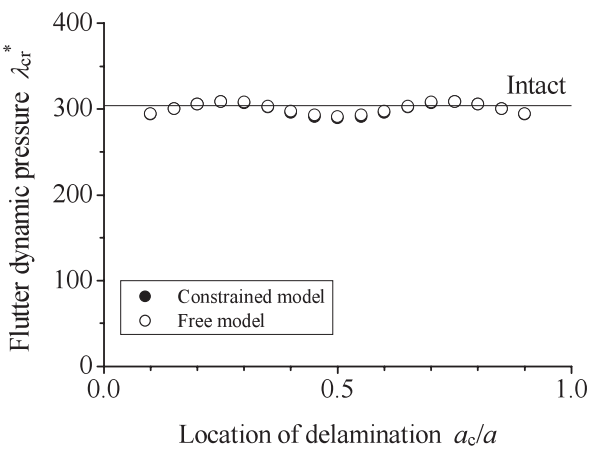

(a) $u_{\mathrm{d}}=0.5$

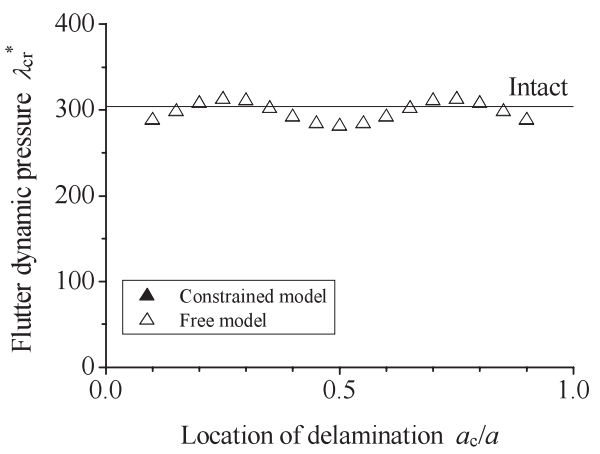

(b) $u_{\mathrm{d}}=0$

第 9 図 はく離の主流方向位置がフラッタ動圧におよぼす影響 $\left(a_{\mathrm{d}} / a=\right.$ $0.10)$

ドの連成によってパネルフラッタが生じる範囲内では，低 次の固有振動モードの直接的な連成以外に，より高次のは く離面が開口する固有振動モードが関与するため，その影 響を受けることにより拘束モデルの場合と比較してフラッ 夕動圧パラメータが高くなる。

第 9 図，第 10 図に，両端単純支持積層はりの層間はく 離の主流方向（ $x$ 軸方向）の位置がフラッ夕動圧パラメー 夕の值におよぼす影響を示す。第 9 図は, はく離の大きさ $a_{\mathrm{d}} / a$ が 0.10 の場合のフラッタ動圧パラメータの值を示し ている. 第 9 図 (a) と第 9 図 (b) の比較により, はく離の 大きさ $a_{\mathrm{d}} / a$ が 0.10 程度では，はく離の板厚方向の位置が フラッタ動圧パラメータにおよぼす影響は小さいことがわ かる。また，この図より，フラッ夕動圧パラメータの值は， はく離が構造の中央に存在する場合に最も低く, 構造の境 界に近づくにつれ大きくなり， $a_{\mathrm{c}} / a=0.25,0.75$ 近傍に 極大值を有することがわかる。ここで，第 11 図に，層間は く離の主流方向の位置が固有角振動数におよぼす影響を示 す。この図において, 縦軸の值は次式に示すようにパネル フラッタが生じる際に連成する 1 次固有振動モードおよび 2 次固有振動モードの固有角振動数の差を表すパラメータ の值である。

$$
R=\frac{\left(\omega_{2}^{*}\right)_{\mathrm{d}}-\left(\omega_{1}^{*}\right)_{\mathrm{d}}}{\left(\omega_{2}^{*}\right)_{\mathrm{i}}-\left(\omega_{1}^{*}\right)_{\mathrm{i}}}
$$

ここで, $\left(\omega_{j}^{*}\right)_{\mathrm{d}},\left(\omega_{j}^{*}\right)_{\mathrm{i}}(j=1,2)$ はそれぞれ，はく離を有 する積層はり，はく離を有さない積層はりの $j$ 次の固有角 振動数である。第 9 図 (b) との比較により, 第 9 図 (b) 中 


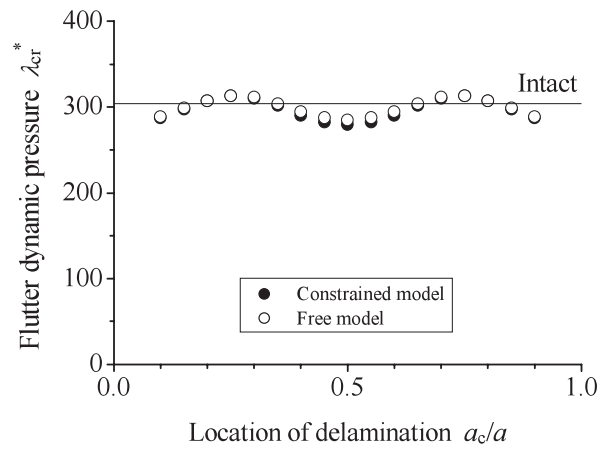

(a) $u_{\mathrm{d}}=0.5$

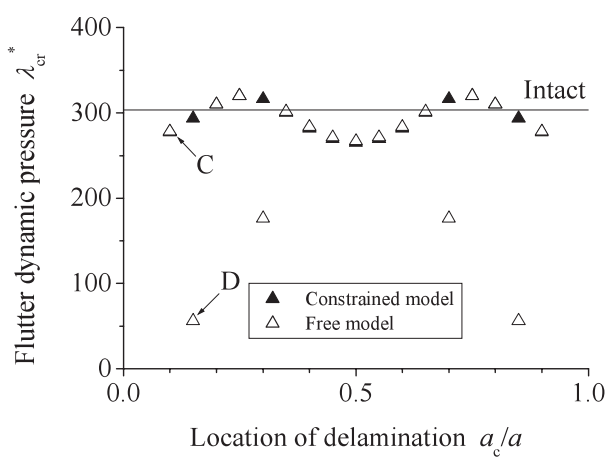

(b) $u_{\mathrm{d}}=0$

第10図 はく離の主流方向位置がフラッタ動圧におよぼす影響 $\left(a_{\mathrm{d}} / a=0.12\right)$

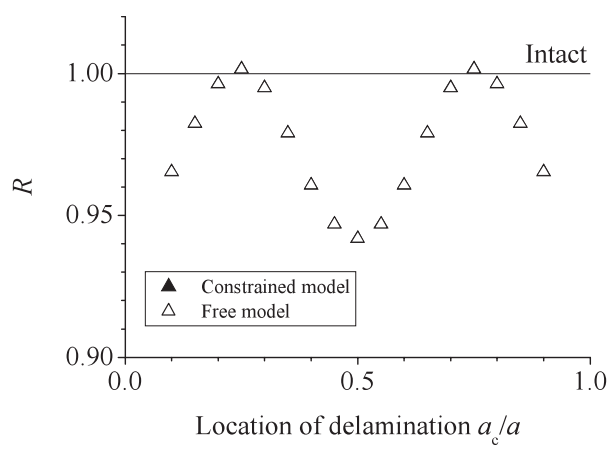

第 11 図 はく離の主流方向位置が固有角振動数におよぼす影響 $\left(a_{\mathrm{d}} / a=0.10, u_{\mathrm{d}}=0\right.$, 自由モデル $)$

のフラッタ動圧パラメータの極大值近傍では，連成する 2 つの固有振動モードの固有振動数の差がはく離を有さない 場合と比較して大きくなり, 結果としてフラッタ動圧パラ メー夕の值が大きくなっていることがわかる，一方，第 10 図は，はく離の大きさ $a_{\mathrm{d}} / a$ が 0.12 の場合のフラッ夕動圧 パラメータの值を示している。この図より, 自由モデルを 用いて得られたフラッタ動圧パラメータの值が急激に変化 する点が存在することがわかる。第 12 図は，第 10 図 (b) 上の $\mathrm{C}$ 点 $\left(a_{\mathrm{c}} / a=0.1\right)$ および $\mathrm{D}$ 点 $\left(a_{\mathrm{c}} / a=0.15\right)$ にお いて，自由モデルを適用した場合に得られるフラッタモー ド形状の比較を示す。ここで, 図中横軸上の太線ははく離 を表している，この図より，C点では，第 7 図 (a) と同様 に低次の固有振動モードの連成によるパネルフラッタが生 じていることがわかる。一方，D点では，第 7 図 (b) と同

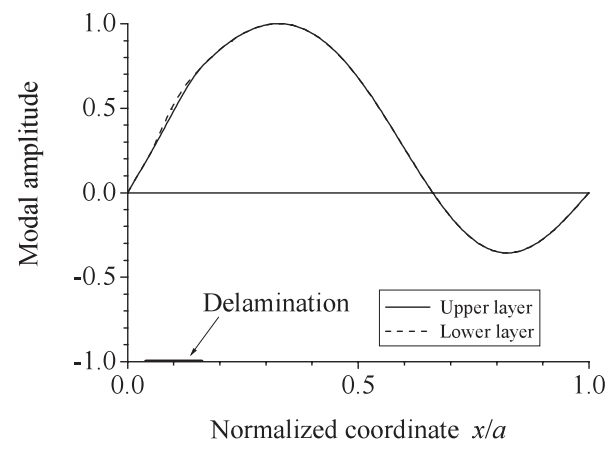

(a) $\mathrm{C}$ 点 $\left(a_{\mathrm{c}} / a=0.1\right)$

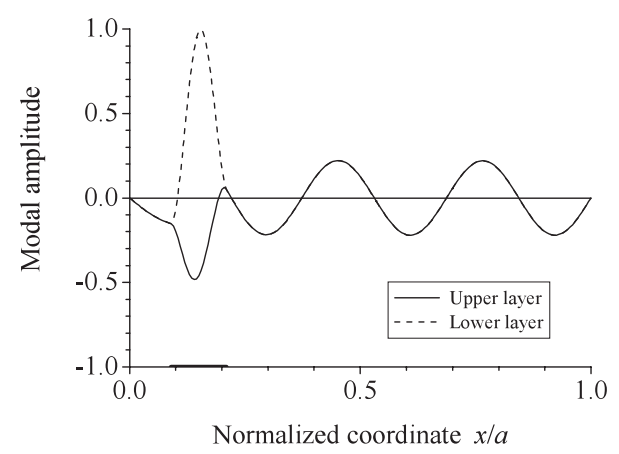

(b) $\mathrm{D}$ 点 $\left(a_{\mathrm{c}} / a=0.15\right)$

第 12 図 フラッタモード形状の比較 $\left(u_{\mathrm{d}}=0\right.$, 自由モデル $)$

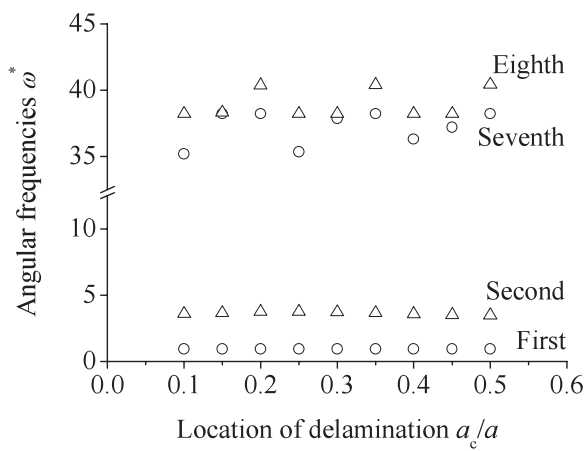

第 13 図 はく離の主流方向位置が固有角振動数におよぼす影響 $\left(a_{\mathrm{d}} / a=0.12, u_{\mathrm{d}}=0\right.$, 自由モデル $)$

様により高次の固有振動モードの連成によるパネルフラッ 夕が生じていることがわかる。ここで，第 13 図に，層間 はく離の主流方向の位置が 1 次 $\cdot 2$ 次, および, 7 次 $\cdot 8$ 次 固有振動モードの固有角振動数におよぼす影響を示す。第 10 図 (b) との比較により, 自由モデルを用いて得られたフ ラッタ動圧パラメータの值の急変は, 7 次固有振動モード, および，8次固有振動モードの固有振動数が他のモードと 比較して非常に近接しており, これらの振動モードが連成 してパネルフラッタが生じることによってフラッタモード の跳び移りが生じることに起因することがわかる.

以上のように， $[0 / 90]_{\mathrm{S}}$ 両端単純支持積層はりを対象とし て，層間はく離の大きさ，および，位置が超音速パネルフ ラッタ特性におよぼす影響に関して検討した結果，はく離の 大きさが構造寸法と比較して十分小さい場合 $\left(a_{\mathrm{d}} / a<0.1\right)$ には，拘束モデル，および，自由モデルの場合で得られる 
フラッタ動圧パラメータの值に差が生じないことから, 固 有值解析に基づいて簡便に得られるパネルフラッタ特性の 妥当性が確認できた。一方，より大きいはく離を有する場 合, はく離の板厚方向, および, 主流方向の位置変化によ るモデル間のフラッタ動圧パラメータの相違が大きく，よ り厳密なパネルフラッタ特性解析の必要性が確認できた。

3.3 層間はく離を有する積層板の超音速パネルフラッタ 特性 数值計算例として第 1 図に示す $[0 / 90]_{\mathrm{s}}$ 周辺単純支 持 CFRP 積層板を考え, その一方向材の材料定数として第 5 表の值を用いた。ここで，アスペクト比 $a / b=1$ の積層 板を対象とし, 積層板内に存在する層間はく離は正方形状 $\left(a_{\mathrm{d}} / b_{\mathrm{d}}=1\right)$ を仮定した. 本解析において, 解析対象とな る積層板を主流方向に 30 分割, 板幅方向に 30 分割したモ デルを用いる。また，(3) 式において採用モード次数は 1 50 次とし, (5) 式により安定性判別の対象となるモード次 数は $1 \sim 20$ 次とした.

第 14 図に, 周辺単純支持積層板の層間はく離の大きさ がフラッ夕動圧パラメータの值におよぼす影響を示す。こ の図より, はく離の板厚方向の位置によらず，拘束モデル， および，自由モデルともにはく離が大きくなるにつれてフ ラッタ動圧パラメータの值が小さくなることがわかる．ま た, はく離の大きさが構造寸法と比較して十分小さい場合 $\left(a_{\mathrm{d}} / a<0.13\right)$ には, 拘束モデル, および, 自由モデルの 場合で得られるフラッタ動圧パラメータの值に差が生じな いが，やや大きくなるとモデル間で差が生じることがわか る、第 15 図は, 第 14 図上の $\mathrm{E}$ 点 $\left(a_{\mathrm{d}} / a=0.13\right)$, およ び, $\mathrm{F}$ 点 $\left(a_{\mathrm{d}} / a=0.2\right)$ において, 自由モデルを適用した 場合に得られるフラッタモード形状の比較を示す。ここで, E 点では, はく離面の開口が生じないことから, 積層板上 面のモード形状のみを示している。 また, 第 15 図 (a) にお いて，太線ははく離を表している。この図より，はく離が 小さい場合には，モデルによらず，第 15 図 (a) に示すよう に $x$ 軸 $\cdot y$ 軸方向に半波数 $m=1, n=1$ のモード $((1,1)$ モード $)$ と $m=2, n=1$ のモード $((2,1)$ モード $)$ の固

第 5 表 CFRP 一方向材の材料定数

\begin{tabular}{ccc}
\hline$E_{1} / E_{2}$ & $G_{12} / E_{2}=G_{13} / E_{2}=G_{23} / E_{2}$ & $\nu_{12}$ \\
\hline 13.643 & 0.493 & 0.32 \\
\hline
\end{tabular}

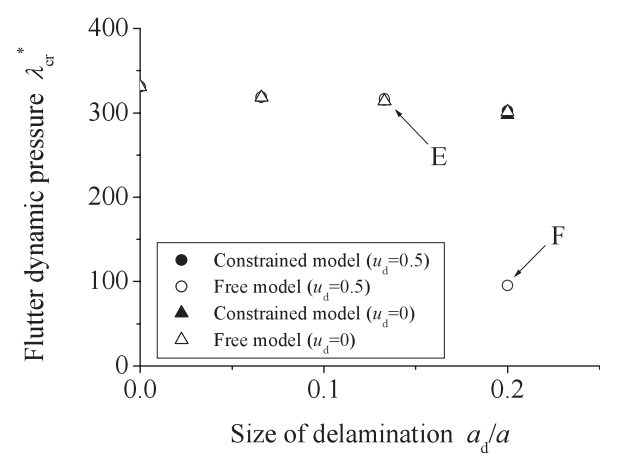

第 14 図 はく離の大きさがフラッ夕動圧におよぼす影響 $\left(a_{\mathrm{c}} / a=\right.$ $\left.b_{\mathrm{c}} / b=0.5\right)$
有振動モードの連成によって半波数 $m=2, n=1$ のモー ド $((2,1)$ モード $)$ のフラッタモード形状を呈するパネル フラッタが生じることがわかる。一方, 第 15 図 (b) と第 15 図 (c) の比較により, はく離が大きい場合には, 自由モ デルを用いた場合により高次の固有振動モードの連成によ る, はく離面が大きく開口するようなパネルフラッタが生 じることがわかる。よって，モデル間のフラッタ動圧パラ メータの值の相違は, パネルフラッタが生じる際に連成す る固有振動モードのモード次数に起因する.

第 16 図は, 周辺単純支持積層板の層間はく離の主流方 向（ $x$ 軸方向）の位置がフラッタ動圧パラメータの值にお よぼす影響を示す．なお，この図は，はく離の大きさ $a_{\mathrm{d}} / a$ が 0.13 の場合のフラッタ動圧パラメータの值を示してい る. 第 16 図 (a) と第 16 図 (b) の比較により, はく離の大 きさ $a_{\mathrm{d}} / a$ が 0.13 程度では, はく離の板厚方向の位置がフ

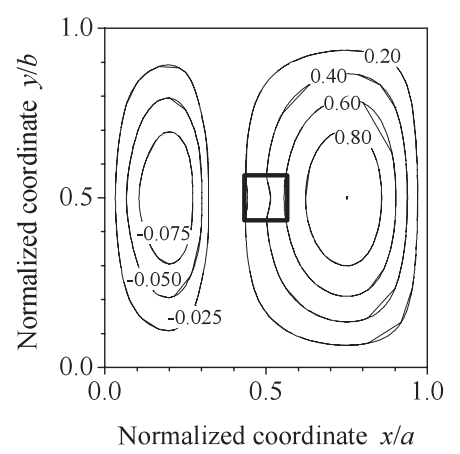

(a) $\mathrm{E}$ 点 $\left(a_{\mathrm{d}} / a=0.13\right)$

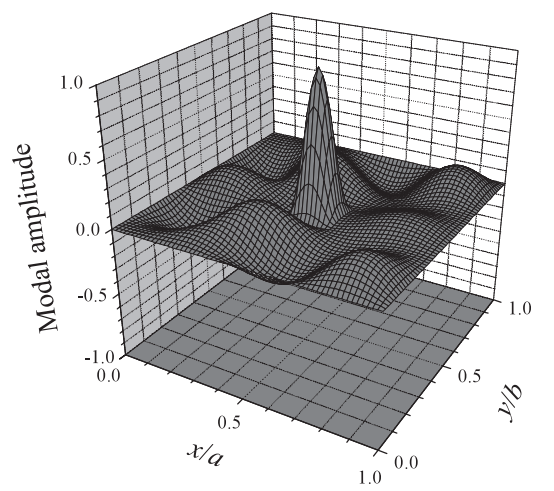

(b) $\mathrm{F}$ 点 $\left(a_{\mathrm{d}} / a=0.2\right)$ における積層板上面のモード形状

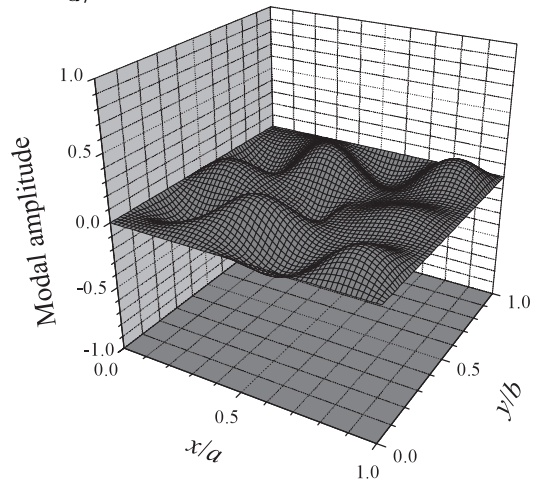

(c) $\mathrm{F}$ 点 $\left(a_{\mathrm{d}} / a=0.2\right)$ における積層板下面のモード形状

第 15 図 フラッタモード形状の比較 $\left(u_{\mathrm{d}}=0.5\right.$, 自由モデル $)$ 


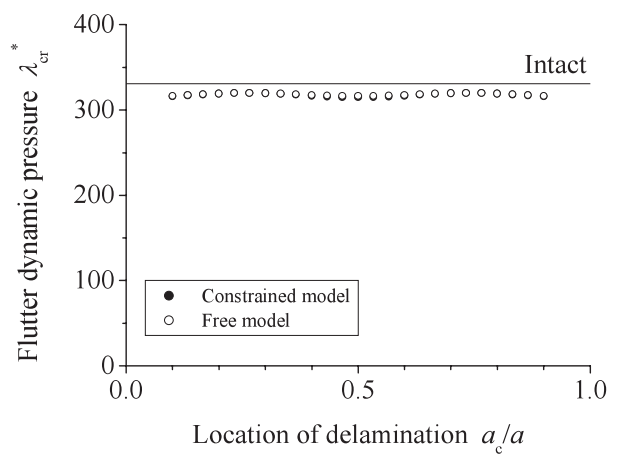

(a) $u_{\mathrm{d}}=0.5$

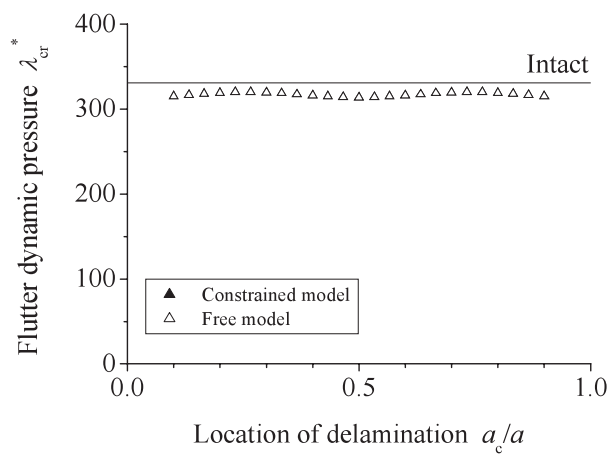

(b) $u_{\mathrm{d}}=0$

第 16 図 はく離の主流方向位置がフラッタ動圧におよぼす影響 $\left(b_{\mathrm{c}} / b=0.5, a_{\mathrm{d}} / a=0.13\right)$

ラッタ動圧パラメータにおよぼす影響は小さいことがわか る。また，この図より，フラッタ動圧パラメータの值は，変 動幅は $2 \%$ 未満となっているものの, 第 9 図, 第 10 図と同 様にはく離が構造の中央に存在する場合に最も低く, 構造 の境界に近づくにつれ大きくなり， $a_{\mathrm{c}} / a=0.25,0.75$ 近 傍に極大值を有することがわかる.

第 17 図は, 周辺単純支持積層板の層間はく離の板幅方 向 ( $y$ 軸方向) の位置がフラッタ動圧パラメータの值におよ ぼす影響を示す．この図は，はく離の大きさ $a_{\mathrm{d}} / a$ が 0.13 の場合のフラッタ動圧パラメータの值を示している.なお, パネルフラッタ解析は, 対称性を考慮し $b_{\mathrm{c}} / b \geq 0.5$ の場合 のみ行っている。第 17 図 (a) と第 17 図 (b) の比較により, 第 16 図と同様にはく離の大きさ $a_{\mathrm{d}} / a$ が 0.13 程度では，は く離の板厚方向の位置がフラッ夕動圧パラメータにおよぼ す影響は小さいことがわかる。また，この図より，構造の境 界近傍においてフラッタ動圧パラメータの值が $2 / 3$ 程度ま で急激に低下していることがわかる，第 18 図は，拘束モデ ルを適用した場合の層間はく離の板幅方向の位置が固有角 振動数, および, フラッタ角振動数におよぼす影響を示す. この図より, 構造の境界近傍において 4 次固有振動モード, および，5次固有振動モードの固有振動数が近づき，これ らの振動モードが連成してパネルフラッタが生じることに よって，第 17 図に見られるようなフラッタ動圧パラメータ の不連続変化が生じることがわかる. 第 19 図は, 第 17 図 (b) 上の $\mathrm{G}$ 点 $\left(b_{\mathrm{c}} / b=0.9\right)$, および, $\mathrm{H}$ 点 $\left(b_{\mathrm{c}} / b=0.8\right)$ において，拘束モデルを適用した場合に得られるフラッタ

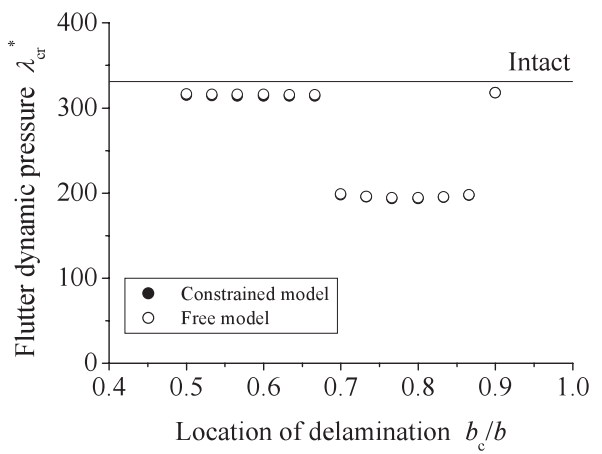

(a) $u_{\mathrm{d}}=0.5$

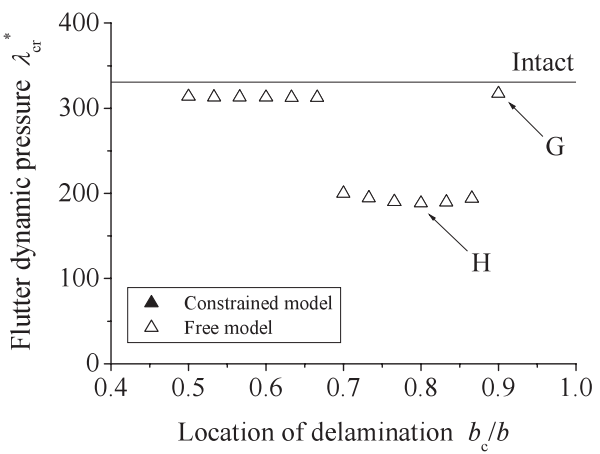

(b) $u_{\mathrm{d}}=0$

第17図 はく離の板幅方向位置がフラッタ動圧におよぼす影響 $\left(a_{\mathrm{c}} / a=0.5, a_{\mathrm{d}} / a=0.13\right)$

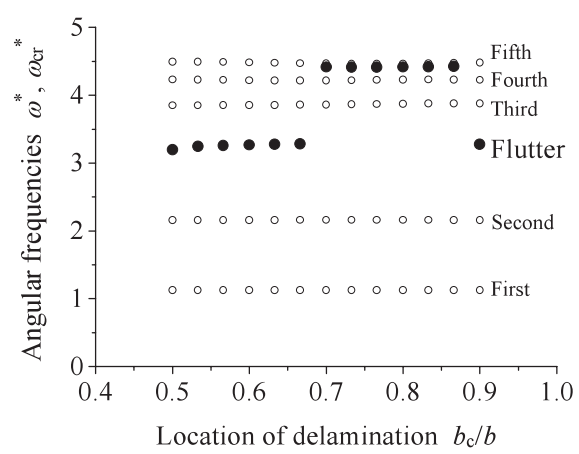

第 18 図 はく離の板幅方向位置がフラッタ角振動数におよぼす影響 $\left(a_{\mathrm{d}} / a=0.13, u_{\mathrm{d}}=0\right.$, 拘束モデル $)$

モード形状の比較を示す。ここで，図中の太線ははく離を 表している，この図より，G点では，第 19 図 (a)に示すよ うに $(1,1)$ モードと $(2,1)$ モードの固有振動モードの連成 によって $(2,1)$ モードのフラッタモード形状を呈するパネ ルフラッタが生じる一方, $\mathrm{H}$ 点では, 第 19 図 (b) に示すよ うに $(1,3)$ モードと $(2,2)$ モードの固有振動モードの連成 によって $(1,3)$ モードのフラッタモード形状を呈する高次 のパネルフラッタが生じることがわかる. なお, 本研究で 対象とした $[0 / 90]_{\mathrm{S}}$ 積層板の場合, 積層構成の効果により, はく離の主流方向の位置と比べて板幅方向の位置がパネル フラッタ特性におよぼす影響が大きくなっていることがわ かる.

以上のように， $[0 / 90]_{\mathrm{s}}$ 周辺単純支持積層板を対象とし て，層間はく離の大きさ，および，位置が超音速パネルフ 


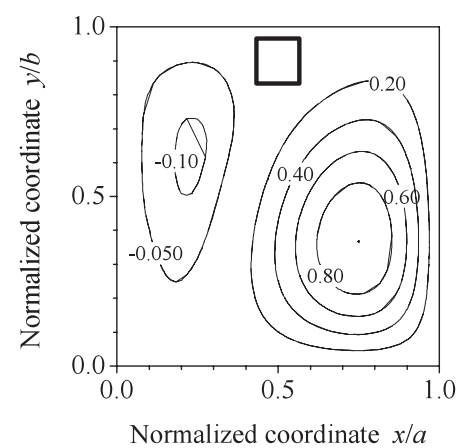

(a) G 点 $\left(b_{\mathrm{c}} / b=0.9\right)$

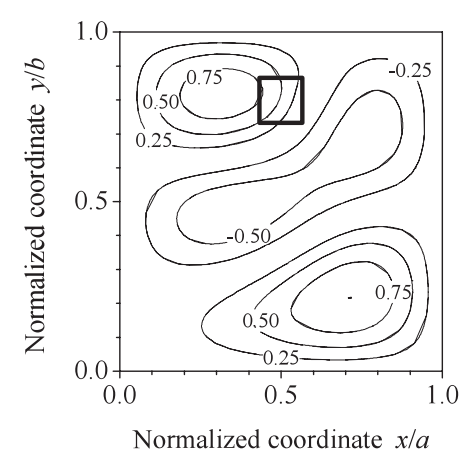

(b) $\mathrm{H}$ 点 $\left(b_{\mathrm{c}} / b=0.8\right)$

第 19 図 フラッタモード形状の比較 $\left(u_{\mathrm{d}}=0\right.$, 拘束モデル $)$

ラッタ特性におよぼす影響に関して検討した結果, 両端単 純支持積層はりの場合と同様に，はく離の大きさが構造寸 法と比較して十分小さい場合 $\left(a_{\mathrm{d}} / a<0.13\right)$ には, 拘束モ デル，および，自由モデルの場合で得られるフラッタ動圧 パラメータの值に差が生じないことから, 固有值解析に基 づいて簡便に得られるパネルフラッタ特性の妥当性が確認 できた。一方，より大きいはく離を有する場合，積層はり と同様に，はく離の板厚方向の位置変化によりモデル間の フラッタ動圧パラメータの相違が大きく, 固有值解析に基 づいた安定性解析の妥当性が失われる。つまり, Shiau ${ }^{12)}$ が言及しているように，拘束モデルを適用して得られたパ ネルフラッタ限界は参考值にとどまるものであり, 自由モ デルを適用した場合についても同様であることから，より 厳密なパネルフラッタ特性解析の必要性が確認できた。

\section{4. 結言}

本論文では，層間はく離を有する対称積層はり，掞よび， 対称積層板を対象として超音速パネルフラッタ解析を行い, はく離の大きさ・位置が積層はり・積層板のパネルフラッ 夕特性におよぼす影響について検討した。本論文において 得られた主要な知見は以下の通りである。

1) $[0 / 90]_{\mathrm{s}}$ 両端単純支持積層はり, および, 周辺単純支持 積層板を対象とした場合, 構造寸法の $10 \%$ 程度以下の大き さのはく離を有する積層構造のパネルフラッ夕特性は, は く離領域のモデル化に依存せず，固有值解析に基づいた安 定性解析が妥当であると考元られることから, 効率的な特 性解析が可能である。
2) 一方，構造寸法の $10 \%$ 程度以上の大きさのはく離を 有する積層構造を対象としたパネルフラッタ特性解析では, 得られるパネルフラッタ特性にモデル依存性が見られ, 固 有值解析に基づいた安定性解析の妥当性が失われる。より 正確なパネルフラッタ特性を得るためには，例えば，はく 離面の接触問題をより厳密に考慮した上での動的応答解析 に基づく特性解析が必須となる。

3) $[0 / 90]_{\mathrm{s}}$ 周辺単純支持積層板を対象とした場合, 構造寸 法の高々 $10 \%$ 程度の大きさのはく離を有する場合であって も, はく離の板幅方向の位置によってはフラッタモードの 跳び移りにより大幅なパネルフラッタ動圧の低下が生じる.

4) はく離を有する積層構造の超音速パネルフラッタ解析 に打いて，はく離面の接触問題を考慮するために仮想バネ の導入に基づいた拘束・自由モデルを適用する場合, 低次 の固有振動モードの連成によってパネルフラッタが生じる 範囲内では, 自由モデルを適用して得られるフラッタ動圧 の方が高くなる.

なお，今後の課題として，はく離領域を含めた構造モデ ル，打よび，空力モデルに扔いて減衰・非線形性を考慮し た厳密なパネルフラッタ解析, 実験との比較検討を行うこ とが挙げられる。

\section{参 考 文 献}

1) Abrate, S.: Impact on Composite Structures, Cambridge University Press, New York, 1998.

2) 小林繁夫: 超音速パネルフラッター, 日本航空学会誌, 11 (1963), pp. $10-20$.

3) Dowell, E. H.: Panel Flutter: A Review of the Aeroelastic Stability of Plates and Shells, AIAA J., 8 (1970), pp. 385399.

4) Bismarck-Nasr, M. N.: Finite Element Analysis of Aeroelasticity of Plates and Shells, Appl. Mech. Rev., 45 (1992), pp. 461-482.

5) Bismarck-Nasr, M. N.: Finite Element in Aeroelasticity of Plates and Shells, Appl. Mech. Rev., 49 (1996), pp. S17S24.

6) 例えば, Pidaparti, R. M. V. and Yang, H. T. Y.: Supersonic Flutter Analysis of Composite Plates and Shells, AIAA J., 31 (1993), pp. 1109-1117.

7) 佐藤正喜, 福永久雄, 関根英樹: 積層パラメー夕による対称積層 板のパネルフラッタ設計, 日本機械学会論文集 C 編, 64 (1998), pp. 1013-1020.

8) Scott, R. C. and Weisshaar, T. A.: Panel Flutter Suppression Using Adaptive Material Actuators, J. Aircraft, 31 (1994), pp. 213-222.

9) Pidaparti, R. M. V.: Free Vibration and Flutter of Damaged Composite Panels, Compos. Struct., 38 (1997), pp. 477-481.

10) Pidaparti, R. M. V. and Chang, C. C.: Finite Element Supersonic Flutter Analysis of Skewed and Cracked Composite Panels, Comput. Struct., 69 (1998), pp. 265-270.

11) Strganac, T. W. and Kim, Y. I.: Aeroelastic Behavior of Composite Plates Subject to Damage Growth, J. Aircraft, 33 (1996), pp. 68-73.

12) Shiau, L. C.: Flutter of Composite Laminated Beam Plates with Delamination, AIAA J., 30 (1992), pp. 2504-2511.

13) Nam, C., Chattopadhyay, A. and Kim, Y.: Aeroelastic Control of Smart Composite Plate with Delaminations, J. Intell. Mater. Syst. Struct., 11 (2000), pp. 868-876.

14) Shen, M. H. H. and Grady, J. E.: Free Vibration of Delaminated Beams, AIAA J., 30 (1992), pp. 1361-1370.

15) Sekine, H., Hu, N., Fukunaga, H. and Natsume, T.: Low Velocity Impact Response of Composite Laminates with a 
Delamination, Mech. Compos. Mater. Struct., 5 (1998), pp. 257-278.

16) Perel, V. Y.: Finite Element Analysis of Vibration of Delaminated Composite Beam with an Account of Contact of the Delamination Crack Faces, Based on the First-Order Shear Deformation Theory, J. Compos. Mater., 39 (2005), pp. $1843-1876$.

17) Ashley, H. and Zartarian, G.: Piston Theory-A New Aerodynamic Tool for the Aeroelastician, J. Aeronaut. Sci., 23 (1956), pp. 1109-1118.

18) Sander, G., Bon, C. and Geradin, M.: Finite Element Analysis of Supersonic Panel Flutter, Int. J. Numer. Meth. Eng., 7 (1973), pp. 379-394.
19) $\mathrm{Hu}, \mathrm{N}$. : Buckling Analysis of Delaminated Laminates with Consideration of Contact in Buckling Mode, Int. J. Numer. Meth. Eng., 44 (1999), pp. 1457-1479.

20) Hu, N., Fukunaga, H., Kameyama, M., Aramaki, Y. and Chang, F. K.: Vibration Analysis of Delaminated Composite Beams and Plates Using Higher-Order Finite Element, Int. J. Mech. Sci., 44 (2002), pp. 1479-1503.

21) Mujumdar, P. M. and Suryanarayan, S.: Flexural Vibrations of Beams with Delaminations, J. Sound Vib., 125 (1988), pp. 441-461.

22) Wang, J. T. S., Liu, Y. Y. and Gibby, J. A.: Vibrations of Split Beams, J. Sound Vib., 84 (1982), pp. 491-502. 